\title{
Complexation of Polyfunctional Organic Guest Molecules by Macrocyclic Polyethers. Complexes of S-tert-Butylisothiuronium Salts with 18-Crown-6 and 1,3-Xylyl-18-crown-5
}

\author{
D. N. Reinhoudt, ${ }^{* \dagger}$ J. A. A. de Boer, ${ }^{\dagger}$ J. W. H. M. Uiterwijk, ${ }^{\ddagger}$ and S. Harkema ${ }^{\ddagger}$ \\ Laboratory of Organic Chemistry and Laboratory of Chemical Physics, Twente University of Technology, \\ 7500 AE Enschede, The Netherlands
}

Received March 22, 1985

\begin{abstract}
Crystalline complexes of $S$-tert-butylisothiuronium perchlorate $\left(t-\mathrm{BuSC}\left(\mathrm{NH}_{2}\right)_{2} \mathrm{ClO}_{4}\right)$ and 18-crown-6 (18C6) and 1,3-xylyl-18-crown-5 (1,3X18C5) with a 1:1 stoichiometry were obtained via extraction. X-ray diffraction analysis showed that in the solid state the guest molecule is coordinated via one of the two $\mathrm{NH}_{2}$ groups to the crown ether. The second $\mathrm{NH}_{2}$ group is bound to the anion. ${ }^{1} \mathrm{H}$ NMR spectroscopy of solutions of these complexes has been interpreted in a similar way. The relative association constant of $t$-BuSC $\left(\mathrm{NH}_{2}\right)_{2} \mathrm{ClO}_{4}$ with $18 \mathrm{C} 6$ compared to $1,3 \mathrm{X} 18 \mathrm{C} 5$ in $\mathrm{CDCl}_{3}$ at $T=293 \mathrm{~K}$ is $K_{\mathrm{rel}}=9.5 \pm 0.5$. Lowering the temperature shows two different resonances for the $\mathrm{NH}_{2}$ hydrogen atoms; the low-field signal corresponds to the $\mathrm{NH}_{2}$ group coordinated to the crown ether and the high-field signal to the $\mathrm{NH}_{2}$ group bound to the anion. The change of free energy of activation for the mutual exchange of $\mathrm{NH}_{2}$ groups in $\mathrm{CDCl}_{3}$ at the coalescence temperature $T_{\mathrm{c}}$ ranges from $\Delta G=13-16 \mathrm{kcal} \cdot \mathrm{mol}^{-1}$ for the studied complexes. Since the rates of complexation-decomplexation of the $\mathrm{NH}_{2}{ }^{+}$-anion and $\mathrm{NH}_{2}-\mathrm{crown}$ ether are fast, the observed slow mutual exchange of $\mathrm{NH}_{2}$ groups between an anion and crown ether site is interpreted by the presence of contact $\mathrm{NH}_{2}{ }^{+}$-anion ion pairs. Within such an ion pair the anion- $\mathrm{NH}_{2}{ }^{+}$exchange may be fast, because it proceeds via a bimolecular reaction mechanism.
\end{abstract}

One objective of our work on macrocyclic polyethers is the design and synthesis of receptor molecules to be used in the selective removal of urea from aqueous solutions. Therefore, we are currently interested in the complexation of urea-type molecules by crown ethers. ${ }^{1}$ Previously, we have shown that 18 -crown-6 $(18 \mathrm{C} 6 ; 1)$ forms a complex with urea in the solid state having a molar 1:5 (18C6:urea) stoichiometry. ${ }^{2}$ In this complex two urea molecules are hydrogen bonded to $18 \mathrm{C} 6$, the remaining urea molecules form hydrogen-bonded layers with a clathrate structure.

In contrast to the interaction with charged molecules crown ethers do form rather weak complexes with neutral molecules, e.g., with nitromethane. ${ }^{3}$ We concluded, therefore, that protonation of the weak base urea, followed by crown ether complexation, might give more stable complexes. For this reason we have focused our attention on the complexation of crown ethers with charged urea-like molecules like guanidinium ${ }^{1}$ and uronium salts. ${ }^{4}$ We have shown before that $18 \mathrm{C} 6$ forms crystalline complexes with uronium nitrate $(1: 1),{ }^{4}$ uronium picrate $(1: 1)$, and uronium $p$-toluenesulfonate $(1: 2) .^{5}$ We also observed that benzo27-crown-9 is able to carry uronium perchlorate from an aqueous to a chloroform phase as a $1: 1$ complex. ${ }^{4}$

In this study we describe the complexation of S-tertbutylisothiuronium salts $\left(t-\mathrm{BuSC}\left(\mathrm{NH}_{2}\right)_{2} \mathrm{X}\right)$ with $18 \mathrm{C} 6$ and 1,3-xylyl-18-crown-5 $(1,3 \mathrm{X} 18 \mathrm{C} 5 ; 2)$. These salts resemble
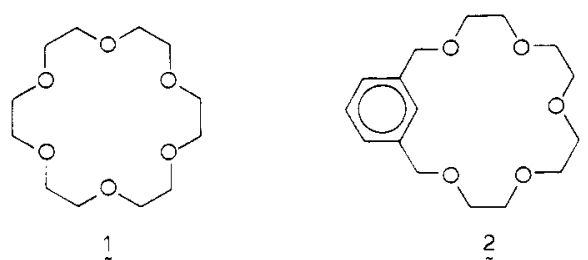

urea in that they have two amino groups in close proximity with four hydrogen atoms that are able to form hydrogen bonds. We can define the $t$-BuSC $\left(\mathrm{NH}_{2}\right)_{2}{ }^{+}$cation as a polyfunctional cation, because it has two conjugated functional groups that share one positive charge. The $t$-BuSC $\left(\mathrm{NH}_{2}\right)_{2} \mathrm{X}$ salts have the advantage over guanidi-

\footnotetext{
${ }^{\dagger}$ Laboratory of Organic Chemistry.

${ }^{\ddagger}$ Laboratory of Chemical Physics.
}

nium and uronium salts that they are more hydrophobic and that they have a convenient ${ }^{1} \mathrm{H}$ NMR probe, viz., the tert-butyl group.

We emphasize that these salts differ fundamentally from $\alpha, \omega$-diammonium alkyl salts $\left(\mathrm{H}_{3} \mathrm{~N}^{+}\left(\mathrm{CH}_{2}\right)_{n}{ }^{+} \mathrm{NH}_{3} \cdot 2 \mathrm{X}^{-}\right)$that may form complexes with cylindrical macrotricyclic polyethers $^{6-13}$ or with binaphthyl bis(crown ethers). ${ }^{14}$ In these salts the two ammonium groups are separated by several methylene groups enabling both functions to complex independently with different parts of the host molecule.

\section{Results and Discussion}

The complexes of crown ethers with $t$-BuSC $\left(\mathrm{NH}_{2}\right)_{2} \mathrm{ClO}_{4}$ were prepared by equilibration of an aqueous solution of $t$-BuSC $\left(\mathrm{NH}_{2}\right)_{2} \mathrm{Cl}$ and $\mathrm{LiClO}_{4}$ with a chloroform solution of the crown ether. The complexes were precipitated by addition of diethyl ether to the separated chloroform layer. Details are given in the Experimental Section.

$\mathbf{X}$-ray Diffraction. The crystal structure of $t$-BuSC$\left(\mathrm{NH}_{2}\right)_{2} \mathrm{ClO}_{4} \cdot 1,3 \mathrm{X} 18 \mathrm{C} 5(1: 1)$ is shown in Figure 1. One of

(1) de Boer, J. A. A.; Uiterwijk, J. W. H. M.; Geevers, J.; Harkema, S.; Reinhoudt, D. N. J. Org. Chem. 1983, 48, 4821.

(2) Harkema, S.; van Hummel, G. J.; Daasvatn, K.; Reinhoudt, D. N. J. Chem. Soc., Chem. Commun. 1981, 368.

(3) de Boer, J. A. A.; Reinhoudt, D. N.; Harkema, S.; van Hummel, G. J.; de Jong, F. J. Am. Chem. Soc. 1982, 104, 4073.

(4) Uiterwijk, J. W. H. M.; Harkema, S.; Reinhoudt, D. N.; Daasvatn K.; den Hertog, H. J., Jr.; Geevers, J. Angew. Chem. 1982, 94, 462.

(5) Uiterwijk, J. W. H. M. Ph.D. Thesis, Twente University of Technology, 1985.

(6) Lehn, J.-M. Acc. Chem. Res. 1978, 11, 49.

(7) Kotzyba-Hibert, F.; Lehn, J.-M.; Vierling, P. Tetrahedron Lett. $1980,941$.

(8) Kotzyba-Hibert, F.; Lehn, J.-M.; Saigo, K. J. Am. Chem. Soc. 1981, 103,4266 .

(9) Kintzinger, J.-P.; Kotzyba-Hibert, F.; Lehn, J.-M.; Pagelot, A.; Saigo, K. J. Chem. Soc., Chem. Commun. 1981, 833.

(10) Pascard, C.; Riche, C.; Cesario, M.; Kotzyba-Hibert, F.; Lehn J.-M. J. Chem. Soc., Chem. Commun. 1982, 557.

(11) Johnson, R. M.; Sutherland, I. O.; Newton, R. F. J. Chem. Soc. Chem. Commun. 1979, 309.

(12) Mageswaran, R.; Mageswaran, S.; Sutherland, I. O. J. Chem. Soc., Chem. Commun. 1979, 722.

(13) Jones, N. F.; Kumar, A.; Sutherland, I. O. J. Chem. Soc., Chem. Commun. 1981, 990 .

(14) Tarnowski, T. L.; Cram, D. J. J. Chem. Soc., Chem. Commun. 1976, 661. Goldberg, I. Acta Crystallogr., Sect. B 1977, B33, 472. 


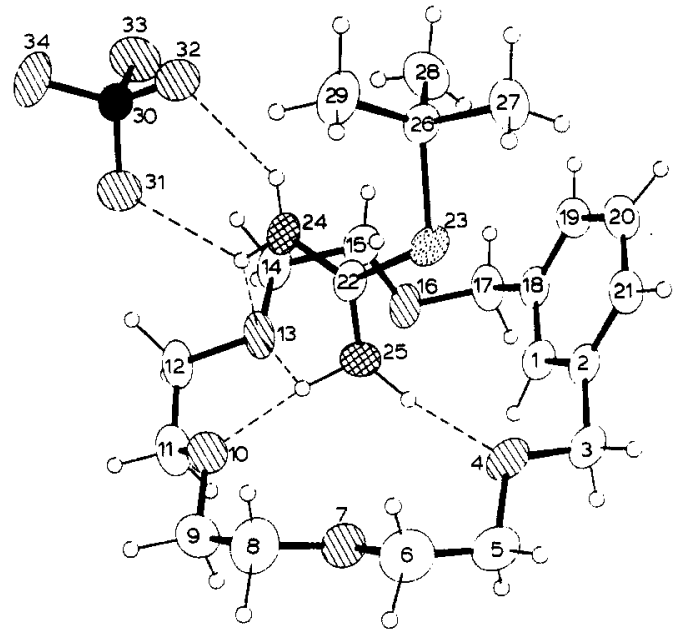

Figure 1. Solid-state structure of $1,3 \times 18 \mathrm{C} 5 \cdot t-\mathrm{BuSC}\left(\mathrm{NH}_{2}\right)_{2} \mathrm{ClO}_{4}$ (1:1) complex from X-ray diffraction analysis.

the two $\mathrm{NH}_{2}$ groups of the $t-\mathrm{BuSC}\left(\mathrm{NH}_{2}\right)_{2}{ }^{+}$cation is hydrogen bonded to the crown ether molecule, forming two strong linear hydrogen bonds (N25 ...04, 2.817 (4) $\AA$, N25-H...04, $171(5)^{\circ}$, and N25...010, 2.929 (4) $\AA$, N25H...O O10, $\left.153(5)^{\circ}\right)$ and a third weaker "hydrogen bond", which is strongly nonlinear (N25...O13, 3.027 (4) $\AA$, N25$\mathrm{H} \ldots \mathrm{O} 13,126(4)^{\circ}$ ). The second $\mathrm{NH}_{2}$ group does not form linear hydrogen bonds. The shortest nonbonded $\mathrm{NH} . . \mathrm{O}$ distances and the associated $\mathrm{N}-\mathrm{H}$... $\mathrm{O}$ angles are as follows: $\mathrm{N} 24 \ldots \mathrm{O} 13,3.087$ (5) $\AA$, with N24-H...O13, $139(5)^{\circ}$; N24...O31, 2.956 (4) $\AA$, with N24-H...O31, 120 (4) ${ }^{\circ}$; $\mathrm{N} 24 \ldots \mathrm{O} 32,2.918$ (5) $\AA$, with $\mathrm{N} 24-\mathrm{H} \ldots \mathrm{O} 32,138(4)^{\circ}$.

From these data can be concluded that both $\mathrm{NH}_{2}$ groups are differently bound. One group interacts with the crown ether, the other to the anion and the crown ether. The mean plane of the crown ether is approximately perpendicular to the plane of the aromatic ring. The $t$-BuSC$\left(\mathrm{NH}_{2}\right)_{2}{ }^{+}$cation and the aromatic ring are on the same side of the crown ether. The macroring adopts the rather un-

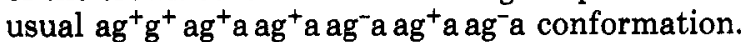

The structure of the $t$-BuSC $\left(\mathrm{NH}_{2}\right)_{2} \mathrm{ClO}_{4} \cdot 18 \mathrm{C} 6(2: 1)$ complex has been published previously. ${ }^{15}$ The crown ether ring has approximately $D_{3 d}$ symmetry; one of the $\mathrm{NH}_{2}$ groups is hydrogen bonded to the crown ether, and the other forms hydrogen bonds to two perchlorate anions.

The determination of the crystal structure of $t$-BuSC$\left(\mathrm{NH}_{2}\right)_{2} \mathrm{ClO}_{4} \cdot 18 \mathrm{C} 6(1: 1)$ was hampered by disorder in one of the two crystallographically independent macrorings in the lattice at $T=150 \mathrm{~K}$.

Static ${ }^{1} \mathbf{H}$ NMR Spectroscopy. The complexation of $t$-BuSC $\left(\mathrm{NH}_{2}\right)_{2} \mathrm{ClO}_{4}$ with $18 \mathrm{C} 6$ and $1,3 \mathrm{X} 18 \mathrm{C} 5$ in solution was studied with ${ }^{1} \mathrm{H}$ NMR spectroscopy. The chemical shift of the $t$-Bu protons is $\delta 1.61$ for the complex with $18 \mathrm{C} 6$ in $\mathrm{CDCl}_{3}$. The corresponding $1,3 \mathrm{X} 18 \mathrm{C} 5$ complex showed a resonance of the $t$-Bu protons at $\delta 1.38$. This upfield shift originates from the shielding effect by the aromatic nucleus. ${ }^{16-19}$ Therefore, the $t$-Bu group and xylyl moiety are on the same face of the crown ether in solution, similar to the observed structure in the solid state. The

(15) Uiterwijk, J. W. H. M.; Harkema, S.; van Hummel, G. J.; Geevers, J.; Reinhoudt, D. N. Acta Crystallogr., Sect. B 1982, B38, 1862.

(16) de Jong, F.; Reinhoudt, D. N. Adv. Phys. Org. Chem. 1980, 17, 279.

(17) de Jong, F.; Reinhoudt, D. N.; Smit, C. J. Tetrahedron Lett. 1976, 1375.

(18) Reinhoudt, D. N.; de Jong, F. Progr. Macrocycl. Chem. 1979, Vol. $1, \mathrm{p} 157$.

(19) de Jong, F.; Reinhoudt, D. N.; Smit, C. J.; Huis, R. Tetrahedron Lett. 1976, 4783 .

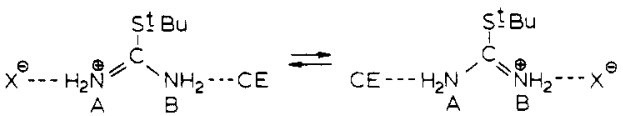

Figure 2. Exchange of amino groups in $\mathrm{CE} \cdot t-\mathrm{BuSC}\left(\mathrm{NH}_{2}\right)_{2} \mathrm{X}$ complexes. $\mathrm{CE}$ is crown ether and $\mathrm{X}^{-}$is the anion.

Table I. Chemical Shifts of tert-Butyl Hydrogen Atoms and Intraannular Aromatic Hydrogen Atoms in $t$-BuSC $\left(\mathrm{NH}_{2}\right)_{2} \mathrm{ClO}_{4} \bullet 1,3 \mathrm{X} 18 \mathrm{C5} \bullet 18 \mathrm{C} 6$ Mixtures at $T=293 \mathrm{~K}^{a}$

\begin{tabular}{cll}
\hline$[1,3 \mathrm{X} 18 \mathrm{C} 5] /[18 \mathrm{C} 6]$ & $\delta_{t-\mathrm{Bu}}$ & $\delta_{\mathrm{H}}$ \\
\hline 0 & 1.61 & \\
0.90 & 1.564 & 7.684 \\
1.23 & 1.537 & 7.663 \\
1.55 & 1.514 & 7.644 \\
2.34 & 1.474 & 7.621 \\
$\infty$ & 1.38 & 7.579
\end{tabular}

${ }^{a}[1,3 \mathrm{X} 18 \mathrm{C} 5]=\left[t-\mathrm{BuSC}\left(\mathrm{NH}_{2}\right)_{2} \mathrm{ClO}_{4}\right]=0.1245 \mathrm{~mol} \cdot \mathrm{L}^{-1}$. Solvent: $\mathrm{CDCl}_{3}$. Shifts are relative to internal tetramethylsilane.

observed chemical shift difference has been used to determine the relative association constant $\left(K_{\text {rel }}\right)$ of $t$ $\operatorname{BuSC}\left(\mathrm{NH}_{2}\right)_{2} \mathrm{ClO}_{4}$ with $18 \mathrm{C} 6$ and $1,3 \mathrm{X} 18 \mathrm{C} 5$. This has been done before ${ }^{16}$ for the corresponding $t-\mathrm{BuNH}_{3} \mathrm{PF}_{6}$ complexes in chloroform. If the free salt concentration is neglected, the observed chemical shift of the $t$-Bu protons $\left(\delta_{\text {obsd }}\right)$ is the weighted average of the chemical shift in the $1,3 \mathrm{X} 18 \mathrm{C} 5$ complex $\left(\delta_{c, 1} 1.38\right)$ and the $18 \mathrm{C} 6$ complex $\left(\delta_{c, 2}\right.$ $1.61)$.

$$
\delta_{\text {obsd }}=X \delta_{c, 1}+(1-X) \delta_{c, 2}
$$

where $X=$ mole fraction of $t$ - BuSC $\left(\mathrm{NH}_{2}\right)_{2} \mathrm{ClO}_{4}$ complexed with $1,3 \mathrm{X} 18 \mathrm{C} 5$.

Increasing the $18 \mathrm{C} 6$ concentration at constant $1,3 \mathrm{X} 18 \mathrm{C} 5$ and $t$-BuSC $\left(\mathrm{NH}_{2}\right)_{2} \mathrm{ClO}_{4}$ concentrations shows a downfield shift of the $t$-Bu hydrogen atoms (Table I). With eq 1 and the mass balance equations, $K_{\text {rel }}$, as defined in eq 2, was calculated to be $K_{\text {rel }}=9.5 \pm 0.5$. Comparison of $K_{\text {rel }}$ with

$$
\begin{aligned}
K_{\mathrm{rel}} & =\frac{K_{18 \mathrm{C} 6}}{K_{1,3 \mathrm{X} 18 \mathrm{C} 5}}= \\
& \frac{\left[18 \mathrm{C} 6 \cdot t \cdot \mathrm{BuSC}\left(\mathrm{NH}_{2}\right)_{2} \mathrm{ClO}_{4}\right][1,3 \mathrm{X} 18 \mathrm{C} 5]}{\left[1,3 \mathrm{X} 18 \mathrm{C} 5 \cdot t-\mathrm{BuSC}\left(\mathrm{NH}_{2}\right)_{2} \mathrm{ClO}\right][18 \mathrm{C} 6]}
\end{aligned}
$$

$K_{\text {rel }}=100$ found for the complexation of $t-\mathrm{BuNH}_{3} \mathrm{PF}_{6}$ with the corresponding two crown ethers ${ }^{17}$ (under similar experimental conditions) shows that the two crown ethers discriminate less for the thiuronium salts than for the ammonium salts.

Upon decreasing the ratio $[1,3 \mathrm{X} 18 \mathrm{C} 5] /[18 \mathrm{C} 6], t$-BuSC$\left(\mathrm{NH}_{2}\right)_{2} \mathrm{ClO}_{4}$ is displaced from the $1,3 \mathrm{X} 18 \mathrm{C} 5$ molecule as monitored by the shift of the intraannular aromatic hydrogen atom (Table $\mathrm{I}, \delta_{\mathrm{H}}$ ). This probe might be useful for the determination of the absolute association constant with 1,3X18C5. Two different series of experiments were performed in order to obtain the association constant. In one series of experiments the chemical shift of this probe varied by the addition of different amounts $1,3 \mathrm{X} 18 \mathrm{C} 5$ to a chloroform solution containing the $1,3 \mathrm{X} 18 \mathrm{C} 5 \cdot t$-BuSC$\left(\mathrm{NH}_{2}\right)_{2} \mathrm{ClO}_{4}$ complex. With the method described before, ${ }^{16,17}$ an association constant of $K_{1,3 \times 18 \mathrm{C} 5}=185 \pm 20$ $\mathrm{L} \cdot \mathrm{mol}^{-1}$ was calculated. In a second series of experiments a chloroform solution containing $1,3 \mathrm{X} 18 \mathrm{C} 5 \cdot t$-BuSC$\left(\mathrm{NH}_{2}\right)_{2} \mathrm{ClO}_{4}$ was diluted from 50 to $2.5 \mathrm{mmol} \cdot \mathrm{L}^{-1}$ successively. However, the observed chemical shifts $\delta_{\mathrm{H}}$ remained almost constant. This makes the determination of an association constant impossible. Probably, the expected chemical shift change due to decomplexation is compensated by chemical shift changes originating from diluting 
Table II. Chemical Shifts of Amino Protons of $t$-BuSC $\left(\mathrm{NH}_{2}\right)_{2} \bullet \mathrm{X}-\mathrm{CE}$ Complexes at Different Temperatures, Their Coalescence Temperature, and Change of Free Energy of Activation ${ }^{a}$

\begin{tabular}{lllllc}
\hline \multicolumn{2}{c}{ complex } & & & & \multicolumn{1}{c}{$\Delta G}$, \\
\cline { 1 - 4 } $\mathrm{X}$ & \multicolumn{1}{c}{$\mathrm{CE}$} & $\mathrm{T}, \mathrm{K}$ & \multicolumn{1}{c}{$\delta_{\mathrm{NH}_{2}}$} & $T_{\mathrm{c}}, \mathrm{K}^{b}$ & $\mathrm{kcal} \cdot \mathrm{mol}^{-1}$ \\
\hline $\mathrm{ClO}_{4}$ & $18 \mathrm{C} 6$ & 246 & $8.22,7.87$ & & \\
$\mathrm{ClO}_{4}$ & & 309 & 8.04 & 265 & 13 \\
& $1,3 \mathrm{X} 18 \mathrm{C} 5$ & 231 & $8.06,7.55$ & 307 & 15 \\
$\mathrm{PF}_{6}$ & & 309 & 7.82 & & \\
$\mathrm{ClO}_{4}, \mathrm{PF}_{6}$ & $1,3 \mathrm{X} 18 \mathrm{C} 5$ & 231 & $8.06,7.26$ & 323 & 16 \\
& $1,3 \mathrm{X} 18 \mathrm{C} 5$ & & $8.06,7.39$ & &
\end{tabular}

${ }^{a} \mathrm{X}$ is the counterion; $\mathrm{CE}$ means crown ether, $18 \mathrm{C} 6=18$-crown6 , and $1,3 \mathrm{X} 18 \mathrm{C} 5=1,3$-xylyl-18-crown-5. Solvent is $\mathrm{CDCl}_{3}$. Shifts are relative to internal tetramethylsilane. ${ }^{b}$ Coalescence temperature.

the solution. This effect has not been studied in more detail. It indicates that association constants determined by this method may be dependent on the concentration scale.

Dynamic ${ }^{1} \mathbf{H}$ NMR Spectroscopy. In all our studied $t$-BuSC $\left(\mathrm{NH}_{2}\right)_{2} \mathrm{X}$ crown ether complexes line broadening and subsequent line splitting of the $\mathrm{NH}_{2}$ resonance upon lowering the temperature was observed. The complexes studied and the relevant data are given in Table II. The observed line splitting reflects a slow mutual exchange process of the $\mathrm{NH}_{2}$ groups of the $t$-BuSC $\left(\mathrm{NH}_{2}\right)_{2}{ }^{+}$cation (Figure 2). The change of free energy of activation $(\Delta G)$ of this exchange process is similar for the different complexes and amounts $\Delta G=13-16 \mathrm{kcal} \cdot \mathrm{mol}^{-1}$. The two resonances observed show that both amino groups are not equivalent. This may originate from strong interactions with the anion and/or the crown ether. Inspection of the chemical shift data presented in Table II shows that the low-field $\mathrm{NH}_{2}$ resonance can be assigned most probably to the amino group interacting with the crown ether. The high-field $\mathrm{NH}_{2}$ resonance is assigned to the amino group associated with the anion. This picture of the complex structure in solution also emerged from the X-ray diffraction analysis of the solid-state complex (vide supra).

In a mixture of $t$-BuSC $\left(\mathrm{NH}_{2}\right)_{2} \mathrm{ClO}_{4}: t$-BuSC$\left(\mathrm{NH}_{2}\right)_{2} \mathrm{PF}_{6}: 1,3 \mathrm{X} 18 \mathrm{C} 5=1: 1: 2$ (molar), under conditions of slow exchange, the $\delta 8.06$ resonance is assigned to the amino group interacting with the crown ether and the $\delta$ 7.39 resonance is the weighted average of the chemical shift of the $\mathrm{NH}_{2}$ group interacting with $\mathrm{ClO}_{4}^{-}(\delta 7.55)$ and $\mathrm{PF}_{6}^{-}$ $(\delta$ 7.26) anion (Table II). Therefore, it is concluded that the anion- $\mathrm{NH}_{2}^{+}$exchange is still fast on the ${ }^{1} \mathrm{H}$ NMR time scale in this experiment.

In a mixture of $t$-BuSC $\left(\mathrm{NH}_{2}\right)_{2} \mathrm{ClO}_{4}: 18 \mathrm{C} 6: 1,3 \mathrm{X} 18 \mathrm{C} 5=$ 2:1:1 (molar), under conditions of slow exchange, a similar observation was made. The chemical shift of the $t$-Bu hydrogen atoms $(\delta 1.51)$, which is very sensitive to the type of crown ether complexed (vide supra), is the weighted average of the chemical shift in the $18 \mathrm{C} 6$ complex ( $\delta 1.61)$, and the $1,3 \mathrm{X} 18 \mathrm{C} 5$ complex ( $\delta 1.38$ ) over the temperature range $220-309 \mathrm{~K}$. The $T_{\mathrm{c}}$ value for the mutual exchange of the $\mathrm{NH}_{2}$ groups was found to be $280 \mathrm{~K}$ which corresponds to a $\Delta G=14 \mathrm{kcal} \cdot \mathrm{mol}^{-1}$. From this experiment, it is concluded that also the crown ether $-\mathrm{NH}_{2}$ exchange is fast on the ${ }^{1} \mathrm{H}$ NMR time scale. Additional evidence for this conclusion comes from $500-\mathrm{MHz}^{1} \mathrm{H}$ NMR spectroscopy on $t$-BuSC $\left(\mathrm{NH}_{2}\right)_{2} \mathrm{ClO}_{4} \cdot 1,3 \mathrm{X} 18 \mathrm{C} 5$ in $\mathrm{CD}_{2} \mathrm{Cl}_{2}$. Upon lowering the temperature from 297 to $193 \mathrm{~K}$ the part of the spectrum assigned to crown ether methylene groups does not change significantly. This contrasts our observation in an earlier study ${ }^{18}$ on $t-\mathrm{BuNH}_{3} \mathrm{X} \cdot 1,3 \mathrm{X} 18 \mathrm{C} 5$ in $\mathrm{CD}_{2} \mathrm{Cl}_{2}$. Then the observation of splitting of the resonance of the benzylic hydrogen atoms into a double doublet and also line broadening of the other methylene hydrogen resonances followed by line splitting at $T=238 \mathrm{~K}$ led to the conclusion of a slow back-to-face interchange process.

Returning to the observation of two noninterchangeable $\mathrm{NH}_{2}$ groups, in combination with the observations of fast anion- $\mathrm{NH}_{2}{ }^{+}$as well as fast crown ether $-\mathrm{NH}_{2}{ }^{+}$exchange processes, we suggest that the anion $-\mathrm{NH}_{2}{ }^{+}$exchange is fast because it proceeds via a bimolecular mechanism. ${ }^{19}$ Therefore, the amino group is interacting continuously with an anion forming a contact ion pair and making mutual interchange of both amino groups unlikely. For steric reasons, such a mechanism seems improbable for the crown ether $-\mathrm{NH}_{2}^{+}$exchange.

Conclusions. The structures of the complexes between $t$-BuSC $\left(\mathrm{NH}_{2}\right)_{2} \mathrm{ClO}_{4}$ and $18 \mathrm{C} 6$ or $1,3 \mathrm{X} 18 \mathrm{C} 5$ in the solid state and in solution are similar. One $\mathrm{NH}_{2}$ group interacts with the crown ether and the other interacts with the anion. The $t$ - BuSC $\left(\mathrm{NH}_{2}\right)_{2} \mathrm{ClO}_{4}$ is more tightly bound to $18 \mathrm{C} 6$ than to $1,3 \mathrm{X} 18 \mathrm{C} 5\left(K_{\mathrm{rel}}=9.5 \pm 5\right)$. The observed slow exchange of $\mathrm{NH}_{2}$ groups in a series of $t$-BuSC $\left(\mathrm{NH}_{2}\right)_{2} \mathrm{X} \cdot \mathrm{CE}$ complexes in solution is interpreted by the presence of a contact $\mathrm{NH}_{2}{ }^{+} \cdot \mathrm{X}^{-}$ion pair. It is suggested that the mutual anion exchange at the $\mathrm{NH}_{2}^{+}$site is fast (as is the mutual $\mathrm{CE}-\mathrm{NH}_{2}$ exchange), since it proceeds via a bimolecular mechanism.

\section{Experimental Section}

NMR Spectroscopy. All ${ }^{1} \mathrm{H}$ NMR spectra were recorded on a Bruker WP $80-\mathrm{MHz}$ apparatus or a Bruker WM $500-\mathrm{MHz}$ apparatus, both equipped with a B-VT-1000 temperature accessor. The temperature was verified with a thermocouple. $\mathrm{Me}_{4} \mathrm{Si}$ was used as the internal standard.

Elemental Analysis. Elemental analyses were carried out by the Elemental Analytical Section of the Institute for Organic Chemistry TNO, Utrecht, The Netherlands, under supervision of W. J. Buis and G. J. Rotscheid.

Determination of the Relative Association Constant. For a series of $\mathrm{CDCl}_{3}$ samples containing $1,3 \mathrm{X} 18 \mathrm{C} 5 \cdot t-\mathrm{BuSC}\left(\mathrm{NH}_{2}\right)_{2} \mathrm{ClO}_{4}$ (1:1) $(0.1245 \mathrm{M})$ and $18 \mathrm{C} 6(0.0533-0.1369 \mathrm{M})$ the chemical shifts of the $t$-Bu group were determined at $293 \mathrm{~K}$. According to eq 1 and 2 the relative association constants of $18 \mathrm{C} 6 \cdot t-\mathrm{BuSC}$ $\left(\mathrm{NH}_{2}\right)_{2} \mathrm{ClO}_{4}$ and $1,3 \mathrm{X} 18 \mathrm{C} 5 \cdot t$-BuSC $\left(\mathrm{NH}_{2}\right)_{2} \mathrm{ClO}_{4}$ complexes have been determined.

Determination of the Association Constant of the 1,3X18C5.t -BuSC $\left(\mathrm{NH}_{2}\right)_{2} \mathrm{ClO}_{4}$ Complex. (a) Excess Crown Ether Method. For a series of $\mathrm{CDCl}_{3}$ samples containing the same amount of $t$ - BuSC $\left(\mathrm{NH}_{2}\right)_{2} \mathrm{ClO}_{4}(0.05 \mathrm{M})$ and different amounts of $1,3 \mathrm{X} 18 \mathrm{C} 5(0.05-0.172 \mathrm{M})$ the chemical shifts of the intraannular hydrogen atom of $1,3 \mathrm{X} 18 \mathrm{C} 5$ were determined at $T$ $=309 \mathrm{~K}$. The observed chemical shift $\left(\delta_{\text {obsd }}\right)$ is given by eq 3 . The association constant was calculated by minimization of the function $F$ (eq 4) as described previously. ${ }^{3}$

$$
\begin{gathered}
\delta_{\text {obsd }}=X_{\mathrm{f}} \delta_{\mathrm{f}}+\left(1-X_{\mathrm{f}}\right) \delta_{\mathrm{c}} \\
F=\sum_{\mathrm{i}}\left[\delta_{\text {obsd }, \mathrm{i}}-X_{\mathrm{f}, \mathrm{i}} \delta_{\mathrm{f}}-\left(1-X_{\mathrm{f}, \mathrm{i}}\right) \delta_{\mathrm{c}}\right]^{2}
\end{gathered}
$$

$\delta_{\mathrm{c}}=$ the chemical shift at complete complexation

$\delta_{\mathrm{f}}=$ the chemical shift in the absence of complexation

$\mathrm{X}_{\mathrm{f}, \mathrm{i}}=$ the mole fraction of uncomplexed crown ether

(b) Dilution Method. For a series of $\mathrm{CDCl}_{3}$ samples containing $1,3 \mathrm{X} 18 \mathrm{C} 5$ and $t$-BuSC( $\left(\mathrm{NH}_{2}\right)_{2} \mathrm{ClO}_{4}$ in a $1: 1$ ratio at different concentrations $(0.05-0.0025 \mathrm{M})$ the chemical shifts of the intraannular hydrogen atom of $1,3 \mathrm{X} 18 \mathrm{C} 5$ were determined at $T=309$ $\mathrm{K}$. The association constant was calculated by minimization of the function $F$ (eq 4).

$\mathrm{X}$-ray Diffraction. X-ray diffraction measurements on $1,3 \mathrm{X} 18 \mathrm{C} 5 \cdot t \cdot \mathrm{BuSC}\left(\mathrm{NH}_{2}\right)_{2} \mathrm{ClO}_{4}(1: 1)$ were made at $T=147 \mathrm{~K}$ on a Philips PW 1100 diffractometer using graphite monochromated $\mathrm{Cu} \mathrm{K} \alpha$ radiation $(\lambda=1.5418 \AA)$. Crystal data: monoclinic, space group $P 2_{1} / n, a=14.082$ (5) $\AA, b=17.049$ (4) $\AA, c=11.058$ (5) 
$\AA, \beta=90.99(3)^{\circ}, Z=4, d_{\mathrm{c}}=1.329 \mathrm{~g} \cdot \mathrm{cm}^{-3}$. Measurement: $\omega-2 \theta$ scan mode, $3^{\circ}<\omega<74^{\circ}$; scan speed, $(\omega) 0.03^{\circ} \mathrm{s}^{-1}$; scan width, $(\omega)(2.0+0.5 \tan \theta)^{\circ} ;$ number of reflections measured, 4875 .

Solution ${ }^{20}$ and refinement ${ }^{21}$ of the structure are based on 4153 reflections with $I>\sigma(I)$. Hydrogen atoms were found in difference Fourier syntheses. The number of parameters refined was 456 : scale factor, extinction parameter, positional parameters of all atoms, and thermal parameters (isotropic for hydrogen atoms, anisotropic for others). The final $R$ factor was $7.8 \%$. The drawings have been made by ORTEP. ${ }^{22}$

Materials. $18 \mathrm{C6} \cdot t-\mathrm{BuSC}\left(\mathrm{NH}_{2}\right)_{2} \mathrm{ClO}_{4}(1: 1)$ was prepared by extraction of an aqueous solution of $t \cdot \mathrm{BuSC}\left(\mathrm{NH}_{2}\right)_{2} \mathrm{Cl}(4$ $\mathrm{mmol} / \mathrm{mL})$ and $\mathrm{LiClO}_{4}(1 \mathrm{mmol} / \mathrm{mL})$ with a solution of $18 \mathrm{C} 6$ in chloroform. The compound was precipitated by addition of diethyl ether to the chloroform layer and recrystallized from ethanol/petroleum ether: $\mathrm{mp} 136-137^{\circ} \mathrm{C} ; 80-\mathrm{MHz}{ }^{1} \mathrm{H} \mathrm{NMR}$ $\left(\mathrm{CDCl}_{3}\right) \delta 8$ (br s, $\left.4 \mathrm{H}, \mathrm{NH}\right), 3.64\left(\mathrm{~s}, 24 \mathrm{H}, \mathrm{CH}_{2}\right), 1.60\left(\mathrm{~s}, 9 \mathrm{H}, \mathrm{CH}_{3}\right)$ Anal. Calcd for $\mathrm{C}_{17} \mathrm{H}_{37} \mathrm{ClN}_{2} \mathrm{O}_{10} \mathrm{~S}\left(M_{r}=497.004\right)$ : C, 41.08; $\mathrm{H}, 7.50$; $\mathrm{Cl}, 7.13 ; \mathrm{N}, 5.64 ; \mathrm{S}, 6.45$. Found: $\mathrm{C}, 41.15 ; \mathrm{H}, 7.64 ; \mathrm{Cl}, 7.00 ; \mathrm{N}$, $5.54 ; \mathrm{S}, 6.36$.

(20) Germain, G.; Main, P.; Woolfson, M. M. Acta Crystallogr., Sect. A 1971, A27, 368-376. Main, P. In "Computing in Crystallography"; Schenk, H. Ed.; Delft University Press: The Netherlands, 1978.

(21) Busing, W. R.; Martin, K. O.; Levy, H. A. ORFLS Report ORNLTM-305, Oak Ridge National Laboratory: Oak Ridge, TN, 1962

(22) Johnson, C. K. ORTEP, Report ORNL-3794, Oak Ridge National Laboratory: Oak Ridge, TN, 1965.
$1,3 \mathrm{X} 18 \mathrm{C5} \cdot t-\mathrm{BuSC}\left(\mathrm{NH}_{2}\right)_{2} \mathrm{ClO}_{4}(1: 1)$ was prepared by extraction of an aqueous solution of $t-\mathrm{BuSC}\left(\mathrm{NH}_{2}\right)_{2} \mathrm{Cl}(4 \mathrm{mmol} / \mathrm{mL})$ and $\mathrm{LiClO}_{4}(4 \mathrm{mmol} / \mathrm{mL})$ with a solution of $1,3 \times 18 \mathrm{C} 5(4 \mathrm{mmol} / \mathrm{mL})$ in chloroform. The compound was precipitated by addition of diethyl ether to the chloroform layer and recrystallized from ethanol: $\mathrm{mp} 106-108^{\circ} \mathrm{C} ; 80-\mathrm{MHz}^{1} \mathrm{H} \mathrm{NMR}\left(\mathrm{CDCl}_{3}\right) \delta 8.04(\mathrm{br}$ $\mathrm{s}, 2 \mathrm{H}, \mathrm{NH}), 7.57(\mathrm{~s}, 1 \mathrm{H}, \mathrm{Ar} \mathrm{H}), 7.50\left(\mathrm{br} \mathrm{s}, 2 \mathrm{H}, \mathrm{NH}_{2}\right), 7.23(\mathrm{~m}$, $3 \mathrm{H}, \mathrm{Ar} \mathrm{H}), 4.56\left(\mathrm{~s}, 4 \mathrm{H}, \mathrm{Ar} \mathrm{CH}_{2}\right), 3.73\left(\mathrm{~s}, 8 \mathrm{H}, \mathrm{OCH}_{2}\right), 3.65(\mathrm{~s}$, $\left.8 \mathrm{H}, \mathrm{OCH}_{2}\right), 1.40\left(\mathrm{~s}, 9 \mathrm{H}, \mathrm{CH}_{3}\right)$. Anal. Calcd for $\mathrm{C}_{21} \mathrm{H}_{37} \mathrm{ClN}_{2} \mathrm{O}_{9} \mathrm{~S}$ $\left(M_{r}=529.049\right):$ C, $47.68 ; \mathrm{H}, 7.05 ; \mathrm{Cl}, 6.70 ; \mathrm{N}, 5.30 ; \mathrm{S}, 6.06$. Found: C, 47.51; H, 7.13; Cl, 6.60; N, 5.64; S, 5.96.

$1,3 \mathrm{X} 18 \mathrm{C} 5 \cdot t \cdot \mathrm{BuSC}\left(\mathrm{NH}_{2}\right)_{2} \mathbf{P F}_{6}(1: 1)$ was prepared by extraction of an aqueous solution of $t-\mathrm{BuSC}\left(\mathrm{NH}_{2}\right)_{2} \mathrm{Cl}(4 \mathrm{mmol} / \mathrm{mL})$ and $\mathrm{LiPF}_{6}(4 \mathrm{mmol} / \mathrm{mL})$ with a solution of $1,3 \mathrm{X} 18 \mathrm{C} 5(4 \mathrm{mmol} / \mathrm{mL})$ in chloroform. The compound was precipitated by addition of diethyl ether and was directly used: ${ }^{1} \mathrm{H}$ NMR $\left(\mathrm{CDCl}_{3}\right) \delta 8.06(\mathrm{br}$ $\mathrm{s}, 2 \mathrm{H}, \mathrm{NH}), 7.57(\mathrm{~s}, 1 \mathrm{H}, \mathrm{Ar} \mathrm{H}), 7.26\left(\mathrm{~m}, 5 \mathrm{H}, \mathrm{Ar} \mathrm{H} \mathrm{H}^{\prime}\right.$ and $\left.\mathrm{NH}\right)$, $4.56\left(\mathrm{~s}, 4 \mathrm{H}, \mathrm{Ar} \mathrm{CH}_{2}\right), 3.76\left(\mathrm{~s}, 8 \mathrm{H}, \mathrm{OCH}_{2}\right), 3.64\left(\mathrm{~s}, 8 \mathrm{H}, \mathrm{OCH}_{2}\right)$, $1.38\left(\mathrm{~s}, 9 \mathrm{H}, \mathrm{CH}_{3}\right)$. Elemental analyses were not performed because $\mathrm{PF}_{6}$ salts are unstable.

Registry No. 18-C-6.t-BuSC $\left(\mathrm{NH}_{2}\right)_{2} \mathrm{ClO}_{4}(1: 1), 98720-12-8$; $1,3-\mathrm{X}-18-\mathrm{C}-5 \cdot t$-BuSC$\left(\mathrm{NH}_{2}\right)_{2} \mathrm{ClO}_{4}(1: 1), 98720-13-9 ; 1,3-\mathrm{X}-18-\mathrm{C}-$ $5 \cdot t-\operatorname{BuSC}\left(\mathrm{NH}_{2}\right)_{2} \mathrm{PF}_{6}(1: 1), 98720-15-1$.

Supplementary Material Available: Tables of atomic coordinates, thermal parameters, bond distances, and bond angles ( 7 pages). Ordering information is given on any current masthead page.

\title{
Substitution of Unactivated Aryl Halides by Thiolate Anions in Polyglymes
}

\author{
Stephen D. Pastor* and Edward T. Hessell \\ Research and Development Laboratories, Plastics and Additives Division, CIBA-GEIGY Corporation, \\ Ardsley, New York 10502
}

Received May 14, 1985

\begin{abstract}
Tetraglyme was found to be a suitable reaction medium to effect the substitution of hexa-, tetra-, tri-, di-, and monochlorobenzenes with sodium alkanethiolates. The substitution of hexa-, tetra-, and trichlorobenzenes by sodium benzenethiolate gave the corresponding (phenylthio)benzenes in tetraglyme, albeit in lower yield. The results of the substitution of chloro-, bromo-, and fluoro-substituted benzenes by an alkanethiolate suggest that an $\mathrm{S}_{\mathrm{N}} \mathrm{Ar}$ mechanism is operative. The effectiveness of the polyglyme as a reaction medium was shown to decrease in the order tetraglyme $>$ triglyme $>$ diglyme $>$ monoglyme.
\end{abstract}

\section{Introduction}

The substitution of aryl halides by thiolate anions continues to be an active area of interest from both a synthetic ${ }^{1}$ and mechanistic ${ }^{2}$ point of view, since the substitution products are the subject of considerable theoretical study. ${ }^{3}$ In particular, hexasubstituted arylthiobenzenes have been shown to function as inclusion hosts, ${ }^{4}$ e.g., the

(1) (a) Campbell, J. R. J. Org. Chem. 1964, 29, 1830. (b) Bradshaw, J. S.; South, J. A.; Hales, R. H. J. Org. Chem. 1972, 37, 2381. (c) Musial, B. C.; Peach, M. E. Phosphorus Sulfur 1977, 3, 41. (d) Beck, J. R.; Yahner, J. A. J. Org. Chem. 1978, 43, 2048. (e) Peach, M. E.; Rayner, E. S. J. Fluorine Chem. 1979, 13, 447. (f) Chianelli, D.; Testaferri, L.; Tiecco, M.; Tingoli, M. Synthesis 1982, 475. (g) Tiecco, M.; Tingoli, M.; Testaferri, L.; Chianelli, D.; Maiolo, F. Synthesis 1982, 478. (h) Landini, D. Montanari, F.; Rolla, F. J. Org. Chem. 1983, 48, 604. (i) Brunelle, D. J. J. Org. Chem. 1984, 49, 1309.

(2) The reaction of unactivated aryl halides with alkanethiolate anions proceeds by a $S_{\mathrm{N}} \mathrm{Ar}$ mechanism; see (a) Cogolli, P.; Maiolo, F.; Testaferri, L.: Tingoli, M.; Tiecco, M. J. Org. Chem. 1979, 44, 2642. (b) March, J. “Advanced Organic Chemistry", 2nd ed.; McGraw-Hill: New York, 1977; pp 584-598.

(3) For an EPR study; see Alberti, A.; Pedulli, G. F.; Tiecco, M.; Testaferri, L.; Tingoli, M. J. Chem. Soc. Perkin Trans. 2 1984, 975

(4) MacNicol, D. D.; McKendrick, J. J.; Wilson, D. R. Chem. Soc. Rev $1978,7,65$ adduct of carbon tetrachloride with hexakis(phenylthio)benzene has a true clathrate structure. ${ }^{5}$

Tiecco and co-workers have advocated the use of hexamethylphosphoric triamide (HMPT) as the solvent of choice for the substitution of activated and unactivated aryl halides by thiolate anions. ${ }^{6}$ Both $N, N$-dimethylacetamide (DMAC) $)^{7}$ and $N, N$-dimethylformamide (DMF) ${ }^{8}$ have been advanced as suitable replacements for the potentially carcinogenic HMPT. Quite recently, our laboratory reported the substitution of activated aryl halides by thiolate anions in triethyleneglycol dimethyl ether (triglyme $)^{9,10}$ including a single example of the substitution

(5) MacNicol, D. D.; Hardy, A. D. V.; Wilson, D. R. Nature (London) $1977,266,611$

(6) (a) Cogolli, P.; Testaferri, L.; Tingoli, M.; Tiecco, M. J. Org. Chem. 1979, 44, 2636. (b) Testaferri, L.; Tingoli, M.; Tiecco, M. Tetrahedron Lett. 1980, 21, 3099. (c) Testaferri, M.; Tingoli, M.; Tiecco, M. J. Org. Chem. 1980, 45, 4376 .

(7) Odorisio, P. A.; Pastor, S. D.; Spivack, J. D.; Rodebaugh, R. K Phosphorus Sulfur 1982, 13, 309.

(8) Testaferri, L.; Tiecco, M.; Tingoli, M.; Chianelli, D.; Montanucci, M. Synthesis 1983, 751 . 71.

(9) Pastor, S. D.; Spivack, J. D.; Hughes, D. W. Sulfur Lett. 1984, 2, 